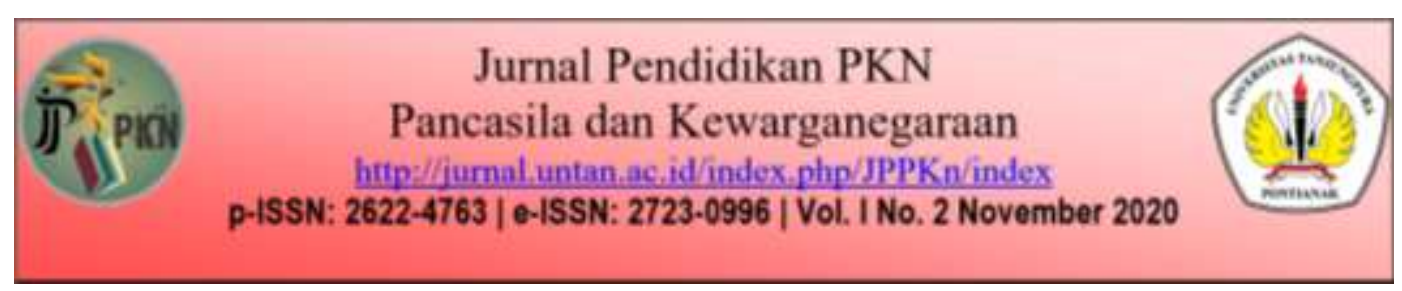

\title{
QUO VADIS: PANCASILA SEBAGAI JIWA HUKUM INDONESIA
}

\author{
Ach Faisol Triwijaya ${ }^{1}$, Yaris Adhial Fajrin ${ }^{2}$, Arif Prasetyo Wibowo ${ }^{3}$ \\ ${ }^{1}$ Magister Ilmu Hukum Universitas Brawijaya, Jl, MT. Haryono 169 Kec. \\ Lowokwaru, Malang, 65145, Indonesia \\ 2Fakultas Hukum Universitas Muhammadiyah Malang, Jl. Raya Tlogomas 2446, \\ Malang, 65144, Indonesia \\ ${ }^{3}$ FKIP Prodi. Civic Hukum Universitas Muhammadiyah Malang, Jl. Raya \\ Tlogomas 2446, Malang, 65144, Indonesia \\ ²yaris@umm.ac.id
}

\begin{abstract}
ABSTRAK
Hukum sebagai pedoman perilaku harus benar-benar bisa menciptakan masyarakat yang tertib, cara yang bisa dilakukan dengan pembentukan hukum yang baik. Menciptakan hukum yang baik bisa dilakukan dengan menggunakan Pancasila sebagai pedoman pembentukan. Namun saat ini yang terjadi beberapa undang-undang tidak mencerminkan hal tersebut, sehingga tercipta hukum yang tidak adil. Indonesia sebagai negara penganut positivisme hukum seharusnya taat dengan hirarki peraturan perundang-undangan dengan mencipta hukum yang sesuai dengan Pancasila. Hukum yang demikian akan mampu melewati berbagai rintangan karena Pancasila yang sifatnya terbuka mampu beradaptasi dengan perkembangan zaman.

Kata Kunci: Hukum Indonesia, Pancasila
\end{abstract}

\begin{abstract}
Law as a code of conduct should create an orderly society, a way that can be done with the establishment of good law. Creating a good law can be done using Pancasila as a guideline for forming. But nowadays some laws don't reflect this so that the laws create unfairly. Indonesia as a state of the positivity of the law should obey the hierarchy of legislation by creating laws that correspond to Pancasila. Such laws will be able to pass through various obstacles because the open-ended Pancasila can adapt to the development of the era.
\end{abstract}

Keywords: Indonesian law, Pancasila 
Jurnal Pendidikan Pancasila dan Kewarganegaraan

Volume I Nomor 2 (November) 2020

\section{PENDAHULUAN}

Negara Indonesia telah memproklamirkan diri sebagai negara yang berdasar kepada hukum. Pilihan konstitusional tersebut membawa konsekuensi jika setiap tindakan oleh Pemerintah harus berdasarkan kepada aturan hukum. Secara teoritis banyak yang menjelaskan bagaimana hukum yang menjadi panglima itu diciptakan, dan hal tersebut sangat dipengaruhi oleh perkembangan mahzab dalam teori hukum. Diantara sekian banyak mahzab, salah satunya yang dikenal adalah mahzab positifisme hukum (legal positivism) yang menginginkan hukum itu berbentuk formal dari negara. Positifisme hukum memandang hukum adalah dari penguasa dengan slogan utamanya legalitas hukum. Bagi kalangan positivistik, aturan yang dianggap tidak adil tetap dianggap sebagai hukum asalkan itu bersumber dari penguasa.

Tokoh dari positifisme hukum adalah Jhon Austin yang menyatakan hukum adalah seperangkat perintah dari penguasa kepada rakyatnya di mana penguasa memiki otoritas tertinggi. Lebih lanjut Austin berpandangan bahwa hukum itu bukan karena berdasar pada kehidupan sosial, bukan juga cerminan keadilan, namun akibat dari mendapat bentuk positif dari institusi yang berwenang yang meliputi kekuasaan, perintah, kewajiban untuk menaati dan sanksi (Effendy, 2014). Hans Kelsen, sebagai murid Austin, selanjutnya memperkenalkan ajaran teori hukum murni yang didalamnya terdapat kajian mengenai gurndnorm, yang berfungsi sebagai bahan bakar dalam sistem perundangan suatu negara (Ali, 2012). Jika dikontekskan Indonesia sebagai sebuah negara maupun sebagai sebuah bangsa maka yang berkedudukan sebagai gurndnorm atau norma dasar (basic norm) dalam hal ini adalah Pancasila (Rahardjo, 2014).

Keterkaitan Pancasila dalam sistem maupun hirarki perundangundangan di Indonesia semakin ditegaskan oleh Pasal 2 Undang-undang No. 12 Tahun 2011 tentang Pembentukan Peraturan PerundangUndangan, yang menentukan bahwa "Pancasila merupakan sumber segala sumber hukum negara" (Purwadi \& Firdausy, 2015). Ketentuan tersebut menegaskan kedudukan Pancasila sebagai dasar yuridis, filosofis, dan ideologi negara, sehingga dalam suatu peraturan perundang-undangan materi muatannya tidak boleh bertentangan dengan nilai-nilai Pancasila. Keberadaan Pancasila sebagai gurndnorm-pun diakui pula oleh Undangundang Dasar Republik Indonesia Tahun 1945 (UUD 1945) pada bagian preambule alinea keempat (Lailam, 2014), sehingga UUD 1945 dalam sistem dan hirarki perundang-undangan Indonesia disebut sebagai "hukum 
Jurnal Pendidikan Pancasila dan Kewarganegaraan

Volume I Nomor 2 (November) 2020

dasar" (Lailam, 2014). Hal tersebut menggambarkan bahwa antara Pancasila dengan UUD 1945 merupakan suatu yang terkait, yang mana Pancasila sebagai landasan idiil dan UUD 1945 sebagai landasan konstituil negara Indonesia. Guna mengawal fungsi Pancasila dan UUD 1945 tersebut pada tahun 2003 dibentuklah Mahkamah Konstitusi (MK) yang didasarkan pada Undang-undang No. 24 Tahun 2003 tentang Mahkamah Konstitusi, sebagai tindak lanjut amandemen ke-3 UUD 1945 (Mahkamah Konstitusi Republik Indonesia, n.d.).

MK merupakan salah satu pelaku kekuasaan kehakiman, yang salah satu kewenangannya adalah dalam hal pengujian undang-undang terhadap UUD 1945. Mengenai pelaksanaan kewenangan MK tersebut, dapat dilihat dari tabel berikut ini mengenai jumlah perkara gugatan materi perundang-undngan dalam 2 tahun terakhir:

Tabel 1. Jumlah Perkara Gugatan Peraturan Perudang-Undangan Tahun 2018-2019

\begin{tabular}{ccccc}
\hline Tahun & $\begin{array}{c}\text { Jumlah } \\
\text { Gugatan }\end{array}$ & Dikabulkan & Ditolak & $\begin{array}{c}\text { Tidak dapat } \\
\text { diterima }\end{array}$ \\
\hline 2018 & 144 & 15 & 42 & 47 \\
\hline 2019 & 93 & 1 & 43 & 33 \\
\hline
\end{tabular}

Sumber: diolah dari berbagai sumber (Mardatillah, 2019; 2020)

Mendasarkan pada tabel di atas, terlihat bahwa tidak sedikit materi muatan di dalam suatu produk peraturan perundang-undangan (baik seluruh maupun sebagian) tidak sesuai dengan UUD 1945, sehingga secara otomatis nilai dan ideologi Pancasila-pun tidak hadir didalamnya yang itu berimplikasi dalam pergaulan hidup berbangsa dan bernegara (Purwadi \& Firdausy, 2015). Terlebih lagi Pasal 5 Undang-undang No. 12 Tahun 2011 mengamanatkan salah satu asas peraturan perundangundangan yang baik haruslah memenuhi asas "kesesuaian antara jenis, hierarki, dan materi muatan".

Kegagalan menaati asas hirarki perundang-undangan menyebabkan peraturan perundang-undangan didalamnya tidak dijiwai oleh Pancasila, sehingga kerap kali suatu perundang-undangan dibatalkan keseluruhan materi muatannya. Semisal, Undang-Undang Nomor 17 Tahun 2012 Tentang Perkoperasian dalam putusan No. 28/PUU-XI/2013, yang berakibat undang-undang tersebut tidak memiliki kekuatan hukum mengikat. Permasalahan sebagaimana yang telah terurai tersebut menggugah penulis untuk melakukan kajian mengenai sejauh mana peraturan perundang-undangan yang berlaku di Indonesia dijiwai oleh 
Jurnal Pendidikan Pancasila dan Kewarganegaraan

Volume I Nomor 2 (November) 2020

Pancasila. Penulis melalui tulisan ini akan memfokuskan kajian pertama, fungsi Pancasila dalam sistem hukum khususnya peraturan perundangundangan. Kedua, sejauh mana Pancasila menjiwai peraturan perundangundangan dan Implikasinya bagi peraturan perundang-undangan terkait.

\section{METODE PENELITIAN}

Metode Penelitian yang digunakan dalam tulisan ini yaitu penelitian hukum normatif, yaitu mengkaji beberapa peraturan kaitannya dengan keberadaan Pancasila dalam jiwa peraturan tersebut. Teknik analisa yang digunakan bersifat deskriptif-analisis dengan memberikan uraian terhadap Pancasila sebagai sumber pembangunan dan pembentukan hukum.

\section{HASIL DAN PEMBAHASAN}

\section{Fungsi Pancasila Dalam Sistem Peraturan Perundang-Undangan}

a. Eksistensi Pancasila sebagai gurndnorm

Mahzab positifisme memiliki the founding father of legal positivism yaitu Jhon Austin yang termahsyur dengan analitical legal positivism. Dasar mahzab ini terletak pada empat poin penting, yaiu penguasa (Souvereighnity), suatu perintah (command), kewajiban untuk menaati (duty), dan terdapat sanksi bagi mereka yang tidak taat (Sudiyana \& Suswoto, 2018). Bagi kalangan penganut positifisme pemisahan antara moral dan hukum merupakan harga mati, sehingga kepastian hukum dalam bentuk aturan tertulis sebagai cara melindungi hukum agar terhindar dari anasir nonhukum. Bagi mereka penganut mahzab legal positivism suatu perundang-undangan yang tidak adil masih relevan dianggap sebagai hukum, sebab menurut Austin berpandangan bahwa hukum itu bukan karena berdasar pada kehidupan sosial, bukan juga cerminan keadilan namun akibat dari mendapat bentuk positif dari institusi yang berwenang yang meliputi kekuasaan, perintah, kewajiban untuk menaati dan sanksi (Effendy, 2014).

Hans Kelsen memberikan ajaran hukum murni (reine rehtslehre) dan memperkaya ajaran dalam mahzab positivisme hukum. Kelsen hendak memisahkan hukum dari anasir-anasir yang sifatnya non-hukum (seperti moral, sejarah, dan lain sebagainya). Tidak terkecuali masalah keadilan, yang menurut Kelsen, hal itu bukan merupakan pembahasan hukum. Sehingga Kelsen memandang hukum sebagai bentuk natural peraturan yang 
dibuat oleh pemerintah (Rasjidi, 1996). Alasan Kelsen menolak hal tersebut karena keadilan berhubungan dengan ideologi yang merupakan wilayah di luar hukum. Sehubungan dengan pemisahan hukum dari faktor non-hukum maka diperlukan sumber yang mampu melahirkan hukum, maka dikenal gurndnorm. Membahas gurndnorm merupakan salah satu pembahasan dalam mahzab positifisme yang sangat penting. Menurut Lon Foller sebagai penganut positifisme hukum, harus ada aturan sebagai pedoman dalam pembuatan keputusan dan aturan-aturan yang dilahirkan tersebut. Artinya gurndnorm memiliki peranan penting karena sebagai pedoman yang berisi kebenaran-kebenaran. Kedudukan gurndnorm sebagai pedoman dasar pembentukan peraturan perundang-undangan kemudian menganggap gurndorm sebagai bahan bakar. Gurndnorm sebagai induk hukum akan melahirkan sejumlah peraturan, secara otomatis tidak boleh bertentangan.

Membicarakan gurndnorm tidak bisa dilepaskan dari ajaran dari Kelsen lainnya yaitu stufenbau theory sebagaimana telah penulis singgung di atas. Keberadaan gurndnorm merupakan satu kesatuan dengan stufenbau theory sebagai teori tata urutan perundangundangan. Ketentuan tata urutan yaitu ketentuan di bawah harus mengikuti yang diatasnya. Ketentuan tertinggi adalah Grundnorm atau norma dasar yang bersifat hipotetis. Dalam tata urutan peraturan perundang-undangan gurndnorm menempati urutan tertinggi dan bersifat abstrak dan semakin membawah akan semakin melebar dan kongkret. Berhubungan dengan pembahasan gurndnorm dalam konteks Indonesia, maka eksistensi Pancasila memiliki peran yang sangat krusial. Notonagoro menempatkan Pancasila sebagai staatsfundamental-norm yang artinya Pancasila merupakan norma dasar dari suatu negara, yang berfungsi sebagai bintang pemandu (Pinasang, 2012). Pendapat Notonegoro tersebut dipengaruhi oleh pendapat Hans Nawianski yang membagi tata urutan perundang-undangan menjadi empat jenis yaitu: pertama, staatsfundamental-norm (norma fundamental negara); kedua, Staatsgrundgesetz (aturan dasar negara); ketiga, Formell Gesetz (undang-undang formal); dan keempat, Peraturan pelaksana (Pinasang, 2012). Tata urutan peraturan perundang-undangan dari seorang Nawianski dipengaruhi oleh Kelsen sekaligus sebagai gurunya. 
Mengutip pendapat dari Latipulhayat bahwa Gurndnorm bukan merupakan norma positif yang keberlakuannya dikehendaki oleh kehendak. Lebih dari itu, gurndnorm adalah norma yang diyakini dalam nalar mereka yang mempercayai (Latipulhayat, 2014). Pancasila yang berisi konsensus-konsensus dari para pendiri bangsa dan telah melalui berbagai kompromi ditengah pluralisme telah diyakini sebagai suatu norma fundamental dan memiliki berbagai fungsi diantaranya sebagai way of life (pandangan hidup) dan sumber dari segala sumber hukum. Kelsen menempatkan gurndnorm sebagai salah satu bagian dari teorinya merupakan salah satu cara menjawab pertanyaan mengapa orang harus patuh kepada hukum. Gurndnorm bukanlah sebuah norma hukum melainkan sebagai meta hukum. dengan demikian Pancasila dalam hal ini layak disebut sebagai gurndnorm karena merupakan landasan yang sifatnya sangat abstrak serta bukan merupakan norma hukum, melainkan melalui Pancasila kemudian diturunkan kepada norma-norma hukum yang lebih konkrit.

Keberadaan hukum dan segala bentuk normanya, tidak boleh terlepas dari tujuan hukum yang dicita-citakan oleh suatu negara. Gustav Radbruch mengemukakan tujuan hukum yang meliputi: kepastian, keadilan dan kemanfaatan (Mustaghfirin, 2011). Sedikit berbeda jika dikaitkan dengan pandangan hukum kodrat sebagaimana yang dikemukakan oleh Thomas Aquinas, yang menjelaskan bahwa "quondam rationis ordination ad bonum commune, ab eo curam communitatis habet, promulgata" (perintah yang masuk akal, bertujuan untuk kesejahteraan umum dibuat oleh mereka yang mengemban tugas suatu masyarakat dan diundangkan), itu artinya bahwa hukum ditujukan untuk mewujudkan kesejahteraan masyarakat umum yang benar-benar dapat dinikmati oleh seluruh masyarakat (Rosadi, 2010), meliputi keadilan, perdamaian, kententraman hidup, keamanan, dan jaminan bagi warganya. Memperhatikan pendapat dua ahli di atas maka hukum Indonesia juga memerlukan tujuan hukumnya sendiri (Sidharta, 2009), sehingga secara realistis diwujudkan dalam norma hukum yang konkrit. Maka sebab itu diperlukanlah peran dan fungsi dari gurndnorm, dalam hal ini adalah Pancasila sebagai cita hukum (rechtsidee) Indonesia (Rosadi, 2010). Memperhatikan hal tersebut maka dalam usaha pembentukan hukum nasional perlu berpatokan pada tujuan hukum yang didasarkan kepada cita hukum Pancasila, 
yang bertujuan memberikan pengayoman atau melindungi manusia, dengan cara menciptakan kondisi kemasyarakatan yang manusiawi secara adil, sehingga tiap-tiap individu memperoleh kesempatan yang sama dan dalam upaya pengembangan seluruh potensi kemanusiaannya secara utuh (Prasetyo, 2014).

Rechtsidee atau cita hukum pada hakekatnya memandang hukum sebagai aturan tingkah laku masyarakat yang berakar pada gagasan, pikiran, rasa, cipta, karsa masyarakat sendiri, yang diwujudkan dalam tiga unsur yaitu: keadilan, kehasilgunaan (doelmatigheid) dan kepastian hukum. Jika dikaitkan dengan usaha pembentukan hukum nasional, maka Pancasila sebagai rechtsidee memiliki peran dan fungsi sebagai berikut: (Rusli, 2011)

a) Sebagai acuan yang bersifat regulatif dan konstruktif;

b) Sebagai motivator dan pedoman (guiding principle) penyelenggaraan hukum (law making process, law enforcement maupun law awareness);

c) Metode dan penjelasan yang relevan untuk ditelaah sebagai kunci pembentukan hukum oleh lembaga-lembaga yang berwenang;

d) Sebagai kaidah evaluasi dalam penegakan hukum, sehingga menjadi "margin of appreciation" (batas-batas pembenaran, tolok ukur tentang etika moral, kehormatan dan martabat) bangsa;

e) Sebagai leitstern (bintang pemandu) tercapainya cita-cita masyarakat.

Tidak berbeda jauh sebagaimana yang dikemukakan oleh Teguh Prasetyo mengenai Pancasila sebagai Rechtsidee, di mana Pancasila dalam hal ini memiliki tiga nilai yaitu, sebagai nilai dasar, sebagai nilai instrumental, dan sebagai nilai praktis (Prasetyo, 2014). Pembentukan hukum nasional guna mewujudkan substansi undang-undang yang baik merupakan jalan untuk mencapai tujuan hukum Pancasila. Sebab secara filosofis, hukum ditujukan untuk mencapai kedamaian, melalui keserasian antara nilai ketertiban dengan ketentraman (Purbacaraka \& Soekanto, 1991).

b. Fungsi Pancasila sebagai bintang pemandu substansi undangundang

Pancasila merupakan bintang pemandu, hal itu berarti bahwa Pancasila memberikan garis-garis yang harus diikuti oleh aturanaturan yang berada dibawahnya begitulah, pendapat Notonegoro (Pinasang, 2012). Sebagai bintang pemandu cita-cita Pancasila 
dikongkritkan melalui aturan-aturan di bawah Pancasila, atau dengan kata lain di sini terdapat suatu aturan main bahwa cita-cita Pancasila harus menjiwai setiap aturan positif. Pembangunan hukum Indonesia memang sudah seharusnya berakar dari nilainilai luhur dalam Pancasila sehingga aturan yang ada sesuai dengan jiwa bangsa (volkgeist) Indonesia (Fatoni, 2015). Hukum yang demikian akan otomatis akan menciptakan hukum yang aspiratif dan akomodatif serta akan berpengaruh terhadap keberlakukannya di masyarakat. Maka fungsi Pancasila sebagai bintang pemandu sama halnya sebagai asas yang melandasi hukum di Indonesia.

Perubahan-perubahan undang-undang dasar yang pernah terjadi tidak pernah mengubah kedudukan Pancasila yakni sebagai gurndnorm, sehingga kedudukannya sangatlah penting dalam kaitannya dengan teori stufenbau theory. Selain sebagai gurndnorm, Pancasila juga sebagai Philosofische Gronslag/dasar filsafat (Kaelan, 2009), sehingga hal tersebut memberikan konsekuensi terhadap setiap aspek kehidupan bangsa yang harus didasarkan pada nilainilai luhur Pancasila. Selain itu, Pancasila juga sebagai norma dasar (staatfundamentalnorm), yang artinya bahwa Pancasila merupakan norma dasar yang lebih lanjut harus dijabarkan di dalam UUD 1945 dan hukum positif Indonesia lainnya (Bunga, 2011). Sebagai staatfundamentalnorm, Pancasila diartikan juga sebagai pokok kaidah negara yang fundamental yang memiliki substansi dan arti yang abstrak, umum, dan universal (Kaelan, 2009).

Misalnya saja pada Undang-Undang Nomor 44 Tahun 200 Tentang Pornografi merupakan undang-undang yang nuansa Pancasilanya sangat kental. Terlihat dari bagian penjelasan umum undang-undang pornografi yang tertulis:

"Pengaturan pornografi berasaskan Ketuhanan Yang Maha Esa, penghormatan terhadap harkat dan martabat kemanusiaan, kebinekaan, kepastian hukum, nondiskriminasi, dan perlindungan terhadap warga negara. Hal tersebut berarti bahwa ketentuan yang diatur dalam UndangUndang ini adalah:

1. Menjunjung tinggi nilai-nilai moral yang bersumber pada ajaran agama;

2. Memberikan ketentuan yang sejelas-jelasnya tentang batasan dan larangan yang harus dipatuhi oleh setiap warga negara serta menentukan jenis sanksi bagi yang melanggarnya; dan 
Jurnal Pendidikan Pancasila dan Kewarganegaraan

Volume I Nomor 2 (November) 2020

3. Melindungi setiap warga negara, khususnya perempuan, anak, dan generasi muda dari pengaruh buruk dan korban pornografi."

Terihat redaksi berasaskan Ketuhanan Yang Maha Esa, merupakan penerapan sila pertama dari Pancasila yaitu meyakini ketentuan-ketentuan ilahi. Ketentuan ilahi menjadi salah satu pedoman dalam sebuah peraturan artinya penerapan nilai-nilai ilahi sebagai ketentuan perbuatan yang dilarang atau dibolehkan. Memang harus diakui sila-sila dalam Pancasila memiliki nilai abstraksi yang sangat tinggi. Akan tetap menurut penulis salah satu upaya mengkongkritkan/membuat praktis sila Ketuhanan Yang Maha Esa tidak terlepas dari bagaimana sejarah pembentukan awal sila ini yang melalui kompromi dari golongan agama non-muslim. Sila pertama dapat dimaknai merupakan sila yang mengamanatkan diterapkannya ketentuan agama dala setiap tindakan yang dalam konteks hukum maka ketentuan agama harus menjiwai peraturan perundang-undangan.

Kemudian ketentuan menghargai harkat dan martabat kemanusiaan merupakan pengamalan sila ke-2. Nilai-nilai keberadaban manusia Indonesia telah termanifestasikan ke dalam berbagai kebudayaan yang tersebar di berbagai suku adat di Indonesia, yang didalamnya mengatur pula mengenai apa yang disebut dengan hukum adat. Hwian Christianto dalam tulisannya menyimpulkan bahwa jika dilihat dari perspektif hukum adat, kesusilaan merupakan masalah yang sangat penting karena terkait dengan persoalan nama baik atau kehormatan seseorang dan keluarga. Setiap pelanggaran-pelanggaran terhadap norma tersebut pada hakikatnya merupakan ancaman serius bagi tatanan nilai masyarakat, sehingga hal tersebut perlu untuk ditentang dan dilarang (Christianto, 2015). Hal ini menggambarkan bahwa adab menjadi suatu standart perilaku yang benar dan patut bagi masyarakat Indonesia, lebih-lebih masyarakat Indonesia sebagai bangsa timur yang memiliki cara pandang dan budaya berbeda dengan bangsa barat.

Dari contoh tersebut nampak jika memang Pancasila memiliki peranan yang sentral dan krusial sebagai pemandu substansi undang-undang. Hal tersebut memiliki makna jika Pancasila menjaga peraturan perundang-undangan dari potensi penyimpangan atau pengingkaran cita-cita bangsa Indonesia yang terkandung didalamnya. Selain itu bersemayamnya nilai-nilai 
Jurnal Pendidikan Pancasila dan Kewarganegaraan

Volume I Nomor 2 (November) 2020

Pancasila dalam peraturan perundang-undangan sebagai perwujudan perintah Pasal 2 Undang-undang Nomor 12 tahun 2011 juga TAP MPRS No XX/MPRS/1966 yang menyatakan pembangunan hukum senantiasa berpedoman kepada Pancasila.

\section{Sejauh Mana Pancasila Menjiwai dan Mengimplikasi Peraturan Perundang-Undangan?}

a. Berbagai peraturan yang dibatalkan keseluruhan oleh MK

Sub-pembahasan ini akan membahas mengenai berbagai peraturan perundang-undangan yang dibatalkan oleh undangundang. Maksud dari pembahasan ini sebagai gambaran bahwa dalam beberapa peraturan nilai-nilai Pancasila tidak menjiwai suatu perundang-undangan. Mahkamah Konstitusi sebagai guardian of constitution dalam pembatalan perundang-undangan karena tidak sejalan dengan UUD NRI 1945 yang secara otomatis juga bertentangan dengan Pancasila memiliki peran penting menjaga sistem perundang-undangan Indonesia agar tetap on the track dalam bingkai Pancasila. Berikut ini akan penulis jabarkan undang-undang yang dibatalkan secara keseluruhan oleh Mahkamah Konstitusi.

1) UU Nomor 7 Tahun 2004 Tentang Sumber Daya Air

Melalui putusan Nomor 85/PUU-XII/2013 Mahkamah Konstitusi membatalkan keseluruhan Undang-undang Nomor 7 tahun 2004 tentang Sumber Daya Air. Dalam pertimbangannya MK memberikan pertimbangan bahwa:

"sebagai unsur yang menguasai hajat hidup orang banyak, air sesuai Pasal 33 ayat (2) dan ayat (3) haruslah dikuasai negara. Sehingga, dalam pengusahaan air harus ada pembatasan ketat sebagai upaya menjaga kelestarian dan ketersediaan air bagi kehidupan. Setidaknya, ada lima poin pembatasan yang ditegaskan MK dalam hal pembatasan pengelolaan air. Pertama, setiap pengusahaan air tidak boleh mengganggu dan meniadakan hak rakyat. Soalnya, selain dikuasai negara, air ditujukan untuk sebesar-besarnya kemakmuran rakyat. Kedua, negara harus memenuhi hak rakyat atas air sebagai salah satu hak asasi manusia, yang berdasarkan Pasal 28I ayat (4) UUD harus menjadi tanggung jawab pemerintah. Ketiga, MK pengelolaan air pun harus mengingat kelestarian lingkungan. Keempat, sebagai cabang produksi yang penting dan menguasai 
hajat hidup orang banyak air menurut Pasal 33 ayat 2 UUD 1945 harus dalam pengawasan dan pengendalian oleh negara secara mutlak. Kelima, hak pengelolaan air mutlak milik negara, maka prioritas utama yang diberikan pengusahaan atas air adalah BUMN atau BUMD" (Hukumonline.com, 2015).

Putusan MK mengenai pembatalan Undang-Undang Nomor 7 Tahun 2004 didasarkan kepada kegagalan pembentuk undangundang memahami rumusan sila keadilan sosial dalam undangundang tersebut. MK dalam hal ini menjadi oase ditengah padang pasir kegersangan undang-undang dari nilai-nilai Pancasila yang penuh dengan kesejukan. Menurut Arief Hidayat sewaktu menjadi ketua MK pernah menyampaikan pendapatnya "selama ini Mahkamah Konstitusi hanya dipandang sebagai guardian of the constitution (penjaga konstitusi) saja, padahal sebenarnya MK juga memiliki peran sebagai guardian of the ideology (penjaga ideologi negara) yaitu Pancasila" (Anggono, 2020). Pernyataan tersebut benar karena memang apabila menjadi penjaga konstitusi maka secara otomatis akan menjadi penjaga Pancasila karena sangat tidak mungkin konstitusi bertentangan dengan ideologi suatu negara. Eksistensi Pancasila di dalam Pembukaan UUD 1945 menandakan jika Pancasila memiliki kedudukan yuridis yang lebih tinggi dari UUD NRI 1945 sehingga apabila suatu peraturan perundang-undangan bertentangan dengan konstitusi maka secara otomatis bertentangan dengan Pancasila.

2) Undang-undang nomor 17 tahun 2012 tentang Perkoperasian

Melalui putusan MK nomor 28/PUU-XI/2013, Mahkamah Konstitusi mencabut keseluruhan Undang-Undang Nomor 17 Tahun 2012 tentang Perkoperasian. Pertimbangan dicabutnya undang-undang terebut karena filosofi koperasi dalam undangundang tersebut bertolak belakang dengan usaha bersama yang bersifat gotong royong sebagaimana pasal 33 ayat (1) UUD 1945. Ditinjau dari Pancasila maka hal tersebut bertentangan dengan sila kelima yaitu keadilan Sosial. Argumentasi tersebut penulis dasarkan kepada butir-butir pengamalan Pancasila (Tap MPR no. I/MPR/2003), yakni butir sila ke-5 antara lain "mengembangkan perbuatan yang luhur, yang mencerminkan sikap dan suasana kekeluargaan dan kegotongroyongan".

Ketentuan dalam undang-undang koperasi yang mengharuskan membeli sertifikat modal koperasi sebagaimaa 
Pasal 68 dan Pasal 69 undang-undan tersebut tidak sesuai prinsip koperasi yang sukarela dan terbuka, serta bertentangan dengan Pasal 33 ayat (1) UUD 1945. Seolah-olah koperasi ini seperti korporasi yang menjual saham untuk menjadi bagian dari RUPS. Dicabutnya Undang-Undang Nomor 17 tahun 2012 tetang Perkoperasian menurut penulis sudah sangat baik karena memang tidak mencerminkan Pancasila di dalam undangundang tersebut, seperti nilai kegotongroyongan.

b. Pancasila telah hilang dari substasi Undang-undang

Pancasila dalam beberapa diskursus disebut sebagai suatu pengejawantahan dari nilai-nilai bangsa dengan tujuan untuk dapat menjadi pegangan perjalanan negara Indonesia. Meskipun dalam legal positivism secara gamblang menolak moral dalam hukum namun tokoh legal positivism Hans Kelsen mengakui bahwa keadilan berasal mutlak dari alam kemudian lebih lanjut agar mencapai keadilan hukum maka dilakukan perubahan ke dalam bentuk formal dan dikenal dengan keadilan bermakna legalitas (Effendy, 2014). Maka situasi tersebut menghasilkan bentuk relasi antara hukum dan moral. Skema relasi tersebut yaitu hukum membutuhkan moral sebagai legitimasi dan moral membutuhkan hukum untuk eksistensi, sebagaimana adagium "quid leges sine moribus?" yang berarti "apa artinya undang-undang kalau tidak disertai moralitas"(Rosadi, 2010).

Kenyataannya dari adanya peraturan yang tidak sesuai dengan Gurndnorm memberikan suatu pembenaran bahwa legal Positivism di Indonesia telah melupakan Gurndnorm dan dengan itu dikatakan bahwa hukum Indonesia tidak bermoral sehingga Legal positivism yang tujuannya menurut Austin untuk menjaga keteraturan melalui produk legislasi yang bersumber pada dua hal yakni otoritas politik dan hukum ilahi, tidak mencerminkan hal tersebut dan otoritas lebih determinan terhadap hukum ilahi. Menurut Stamler hukum merupakan materi dari kemauan untuk menciptakan hidup yang teratur dan hukum merupakan kehendak bersama bukan golongan (Tanya, Simanjuntak, \& Hage, 2013). Dalam konteks gurndnorm Indonesia yaitu Pancasila yang merupakan kehendak bersama untuk tujuan hidup yang teratur apabila ada peraturan yang tidak sesuai dengan Pancasila dapat dikatakan itu bukan hukum karena bukan kehendak umum. 
Dengan demikian legal positivism dengan argumentasi sumber hukum aliran tersebut berasal dari dua sumber yaitu kekuasaan politik dan hukum ilahi pada pelaksanaannya cenderung lebih bersumber pada kekuasaan politik. Dapat dilihat dari dilupakannya gurndnorm yang dalam keseluruhan pancasila yang didalamnya terdapat nilai-nilai ilahi yang tentu saja berlandaskan moral. Kemudian muncul pertanyaan mengenai aliran yang tepat diterapkan apakah hukum alam atau legal positivism, maka penulis mengatakan bahwa aliran yang pas adalah perpaduan dari keduanya di mana hukum dalam arti perundang-undangan atau dalam bentuk formal yang merupakan ciri dari legal positivism harus berlandaskan kepada moral, dan apabila norma dasar atau gurndnorm sudah memiliki nilai-nilai kebajikan maka aturan dibawahnya harus sesuai dan tidak bertentangan dengan gurndnorm sebagaimana dalam kaidah stufenbau theory. Hendaknya penganut legal positivism konsisten dan setia terhadap ajarannya.

Padahal apabila memperhatikan sentralnya kedudukan Pancasila yang memiliki peranan penting, seharusnya Pancasila tidak dilupakan pada kebijakan-kebijakan hukum, terlebih Indonesia sebagai negara hukum. Menurut Syahran Basah, Indonesia sebagai negara hukum Pancasila, maka kebijakankebijakan penguasa terjamin guna mengayomi masyarakat karena keberadaan fungsi Pancasila (Pinasang, 2012). Apabila terjadi pengingkaran melalui peraturan yang tidak dijiwai oleh Pancasila, maka negara hukum Pancasila hanyalah sebuah angan-angan saja. Menurut Rudolf Stamler, rechtsidee sebagai keharusan yang diinginkan masyarakat (Anggono, 2020), sehingga keberadaan Pancasila, menurut Mahfud MD, merupakan penuntut hukum. Artinya, hukum yang diciptakan tidak boleh menyebabkan kerugian bagi pihak masyarakat sehingga mampu menciptakan hukum yang berkeadilan sosial. Maka tidak dibenarkan apabila terjadi hukum yang bertentangan dengan Pancasila karena secara otomatis akan merugikan rakyat.

Pada era globalisasi yang banyak mempengaruhi pelbagai sektor kehidupan telah banyak memicu perubahan-perubahan diberbagai sektor kehidupan. Demikian juga mengenai pembentukan hukum yang bisa saja pengaruh-pengaruh modernisasi membelenggu pembentukan peraturan perundangundangan yang seharusnya berpedoman kepada Pancasila. Sebagai 
sebuah konsesus kebangsaan maka Pancasila masih akan relevan dalam pembangunan dan pembentukan hukum sekarang dan masa yang akan datang (Rosadi, 2010). Hilangnya jiwa Pancasila dari dalam hukum Indonesia saat ini perlu menjadi peringatan keras bahwa sudah saatnya Pancasila menjadi rechtsidee dan menjadi cahaya pemandu hukum Indonesia. Kegagalan dunia asing yang ikut mengintervensi berbagai permasalahan di Indonesia akhirakhir ini harus menjadi gambaran jika Pancasila merupakan sebenar-benarnya landasan dalam bernegara termasuk dalam upaya pembangunan hukum nasional yang difungsikan sebagai sarana perlindungan segenap bangsa dan seluruh tumpah darah Indonesia, cita-cita dan tujuan bangsa dan masyarakat Indonesia, serta individu-individunya, jiwa, kebebasan individu, kehormatan, dan harta bendanya, serta pelaksanaan pembangunan. Sehingga hukum harus berfungsi sebagai sarana penunjang perkembangan modernisasi dan pembangunan yang menyeluruh (Darmodiharjo \& Sidharta, 2008).

\section{KESIMPULAN}

Indonesia sebagai penganut mahzab positivism hukum yang menerapkan hirarki/tata urutan peraturan perundang-undangan dalam sistem hukumnya telah banyak melupakan Pancasila. Padahal Pancasila sebagai konsensus kebangsaan telah diultuskan menjadi sumber pembentukan hukum. Sudah saatnya mengembalikan Pancasila sebagai dasar pembentukan hukum di Indonesia agar tercipta hukum yang dapat diterima oleh masyarakat.

\section{DAFTAR PUSTAKA}

Ali, A. (2012). Menguak Teori Hukum (Legal Theory) Dan Teori Peradilan (Judicial Prudence) Termasuk Interpretasi Undang-Undang (Legisprudence) - Vol.1 Pemahaman Awal. Jakarta: Kencana.

Anggono, B. D. (2020). Telaah Peran Partai Politik untuk Mewujudkan Peraturan Perundang-Undangan yang Berdasarkan Pancasila. Jurnal Konstitusi, 16(4), 695-720.

Bunga, D. (2011). Penanggulangan Pornografi dalam Mewujudkan Manusia Pancasila. Jurnal Konstitusi, 8(4), 453-478.

Christianto, H. (2015). Eksistensi Hak Atas Materi Pornografi Berdasarkan Norma Kesusilaan. Veritas et Justitia, 1(1), 61-90.

Darmodiharjo, D., \& Sidharta. (2008). Pokok-pokok Filsafat Hukum: Apa dan 
Jurnal Pendidikan Pancasila dan Kewarganegaraan

Volume I Nomor 2 (November) 2020

Bagaimana Filsafat Hukum Indonesia. Jakarta: Gramedia Pustaka Utama. Effendy, M. (2014). Teori Hukum dari Perspektif Kebijakan, Perbandingan dan Harmonisasi Hukum Pidana. Jakarta: Gaung Persada Press Group (Referensi).

Fatoni, S. (2015). Pembaruan Hukum Pidana Melalui Aktualisasi NilaiNilai Pancasila Berorientasikan Pendekatan Religius. Ahkam: Jurnal Hukum Islam, 3(1), 43-66.

Hukumonline.com. (2015). MK Batalkan UU Sumber Daya Air: Pengelolaan SDA harus diserahkan pada BUMN maupun BUMD. Retrieved from Hukumonline.com website: https://www.hukumonline.com/berita/baca/lt54e4bd8e5dc0a/mkbatalkan-uu-sumber-daya-air

Kaelan. (2009). Filsafat Pancasila: Pandangan Hidup Bangsa Indonesia (ketiga). Yogyakarta: Paradigma.

Lailam, T. (2014). Konstruksi Pertentangan Norma Hukum dalam Skema Pengujian Undang-Undang. Jurnal Konstitusi Mahkamah Konstitusi, 11(1), 19-42.

Latipulhayat, A. (2014). Khazanah: HANS KELSEN. Padjajaran Jurnal Ilmu Hukum, 1(1), 196-208.

Mahkamah Konstitusi Republik Indonesia. (n.d.). Sejarah Pembentukan Mahkamah Konstitusi. Retrieved from Mahkamah Konstitusi RI website: https://mkri.id/index.php?page=web.ProfilMK\&id=1

Mardatillah, A. (2019). 2018, MK Hanya Kabulkan 15 Pengujian UU. Retrieved from Hukumonline.com website: https://www.hukumonline.com/berita/baca/lt5c500a0822228/2018-mk-hanya-kabulkan-15-pengujian-uu/

Mardatillah, A. (2020). MK Hanya Kabulkan 4 Pengujian UU Sepanjang 2019. Retrieved from Hukumonline.com website: https://www.hukumonline.com/berita/baca/lt5e0dd5560211b/mkhanya-kabulkan-4-pengujian-uu-sepanjang-2019/

Mustaghfirin, H. (2011). Sistem Hukum Barat, Sistem Hukum Adat, Dan Sistem Hukum Islam, Menuju Sebagai Sistem Hukum Nasional Sebuah Ide Yang Harmoni. Jurnal Dinamika Hukum, 11(Edisi Khusus).

Pinasang, D. (2012). Falsafah Pancasila Sebagai Norma Dasar (Grundnorm) Dalam Rangka Pengembanan Sistem Hukum Nasional. Jurnal Hukum Unsrat, 20(3), 1-10.

Prasetyo, T. (2014). Membangun Hukum Nasional Berdasarkan Pancasila. Jurnal Hukum Dan Peradilan, 3(3), 213-222.

Purbacaraka, P., \& Soekanto, S. (1991). Ikhtisar Antinomi : Aliran Filsafat 
Jurnal Pendidikan Pancasila dan Kewarganegaraan

Volume I Nomor 2 (November) 2020

Sebagai Landasan Filsafat Hukum. Jakarta: Rajawali Pers.

Purwadi, H., \& Firdausy, A. G. (2015). Konsekuensi Transplantasi Hukum Terhadap Pancasila Sebagai Norma Dasar dan Hukum Lokal. Yustisia, 4(1), 73-88.

Rahardjo, S. (2014). Ilmu Hukum (kedelapan). Bandung: Citra Aditya Bakti. Rasjidi, L. (1996). Dasar-dasar Filsafat Hukum. Bandung: Citra Aditya Bakti. Rosadi, O. (2010). Hukum Kodrat, Pancasila Dan Asas Hukum Dalam Pembentukan Hukum Di Indonesia. Jurnal Dinamika Hukum, 10(3), 282-290.

Rusli, T. (2011). Pembangunan Hukum Berdasarkan Cita Hukum Pancasila. Pranata Hukum, 6(1), 31-42.

Sidharta, B. A. (2009). Refleksi tentang struktur ilmu hukum : sebuah penelitian tentang fundasi kefilsafatan dan sifat keilmuan hukum sebagai landasan pengembangan ilmu hukum nasional Indonesia. Bandung: Mandar Maju.

Sudiyana, S., \& Suswoto, S. (2018). Kajian Kritis Terhadap Teori Positivisme Hukum Dalam Mencari Keadilan Substantif. Jurnal Ilmiah Ilmu Hukum Qistie, 11(1), 107-136.

Tanya, B. L., Simanjuntak, Y. N., \& Hage, M. Y. (2013). Teori Hukum: Strategi Tertib Manusia Lintas Ruang dan Generasi. Yogyakarta: Genta Publishing. 